\title{
Vybrané právní aspekty otroctví v Hostině u Trimalchiona
}

\author{
Lenka Skoupá
}

\author{
Právnická fakulta, Univerzita Karlova \\ Kontaktni e-mail: lskoupa0@gmail.com
}

\section{Selected Aspects of Slavery in Dinner at Trimalchio's}

\begin{abstract}
:
This paper deals with the portrayal of slavery in the specific chapter of Petronius' Satyricon. The main aim of the paper is to compare the information we gain about slavery from the legal sources with the way these institutions are then portrayed within the Satyricon. Specifically, the paper focuses on the legal aspects of entry into slavery (birth, self-sale), transfer of ownership (sale and warranty for goods) and manumission.
\end{abstract}

Keywords: Roman law; Satyricon; slavery; self-sale; sale of slaves; warranty for goods; manumissio inter amicos; manumissio testamento; manumissio per mensam

Klíčová slova: římské právo, Satyricon; otroctví; dobrovolný prodej do otroctví; prodej otroků; ručení za vady; manumissio inter amicos; manumissio testamento; manumissio per mensam

DOI: $10.14712 / 2464689 X .2021 .34$

V právním myšlení starověku byl otrok věcí, a to specificky věcí mancipační. ${ }^{1}$ Toto pojetí však nemohlo být všeobsáhlé. Tak i v pojednáních starověkých autorů se dozvídáme, že kromě toho byl otrok zároveň vnímán jako člověk, ${ }^{2}$ byt člověk nesvobodný. ${ }^{3} \mathrm{~V}$ důsledku je tak otrok podřízen „moci cizí osoby, která mu přikazuje, co smí a co nesmí“. 4

K tomuto právnímu postavení otroka se pak připojovaly další ekonomické a sociální faktory, které specifičnost postavení otroka mohly jedině umocňovat. Tyto faktory jsou určitým způsobem reflektovány v Satirikonu. Je to sice fiktivní dílo, nicméně svým

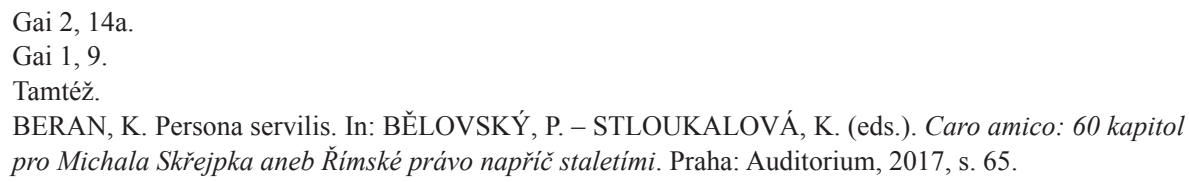


zaměřením na otroky a propuštěnce v kapitole Hostina u Trimalchiona poskytuje ojedinělý obrázek starověkého Ríma tohoto období.

Tato práce se bude zabývat, na př́kladu kapitoly Hostina u Trimalchiona, využitelností tohoto díla pro účely zkoumání toho, jakým způsobem se antická právní věda a společnost vyrovnávaly se starověkou dichotomií v pojetí otroka. Z tohoto důvodu bude porovnávána naše představa o vybraných právních aspektech otroctví se svědectvím obsaženým v Satirikonu. Specificky se práce bude věnovat institutům, které samy o sobě vystihují podstatu dichotomie v pojetí otroků, tedy institutům vzniku a zániku otroctví, jakož i nabývání otroků.

\section{Celkový kontext díla Satirikon}

Před samotným rozborem právních institutů je nutné se seznámit se zkoumaným dílem jako takovým. Satirikon je jedním z nejzajímavějších a nejrozporuplnějších dochovaných děl antické literatury. Vypráví, kombinací prozaické a poetické formy, ${ }^{5}$ o dobrodružstvích Encolpia a jeho přátel. Bohužel se dílo dochovalo pouze ve zlomcích. Vzhledem k neúplnosti díla je tak složité udělat si o něm komplexní představu.

O autorství samotného Satirikonu panují určité pochybnosti, nicméně nejspíše se jedná o dílo neronovského Petronia Arbitra. ${ }^{6}$ Naše informace o něm pocházejí z pera historika Tacita. ${ }^{7}$ Petronius Arbiter, plným jménem zřejmě Petronius Niger, ${ }^{8}$ byl správcem provincie Bithynie a vykonával také konzulský úrúad. ${ }^{9}$ Posléze působil na dvoře císaře Nerona na přelomu poloviny 1 . století n. 1. jako arbiter elegantiae. ${ }^{10} \mathrm{~V}$ rámci druhé vlny pisonovských konspirací11 byl pak obviněn $z$ účasti na spiknutí a po neúspěšném pokusu o obhajobu se rozhodl raději spáchat sebevraždu než čekat na rozsudek. ${ }^{12}$ Zemřel roku 66 n. $1 .{ }^{13}$ v nemilosti císařského dvora, ale jako dlouholetý člen vládnoucí elity.

O př́islušnosti Satirikonu k určitému žánru nepanuje konsensus. Jak již bylo řečeno, Satirikon je fikcí. ${ }^{14}$ Bližší zařazení díla je však pro jeho fragmentárnost komplikované. Mluví se o inspiraci menippskou satyrou či řeckým románem, ${ }^{15}$ jakož i římskou pantomimou. ${ }^{16} \mathrm{~S}$. Harrison pak např́klad v Satirikonu podtrhuje parodizující a komické

5 CONNORS, C. M. Petronius the Poet. Cambridge: Cambridge University Press, 2009, s. 2.

6 DRINKWATER, J. F. (ed.). Nero: Emperor and Court. Cambridge: Cambridge University Press, 2018, s. 101, VOUT, C. The Satyrica and Neronian Culture. In: PRAG, J. - REPATH, I. (eds.). Petronius: a Handbook. Singapore: Blackwell Publishing Ltd., 2009, s. 101, pro porovnání např́íklad ROTH, U. Liberating the cena. The Classical Quarterly, 2016, Vol. 66, No. 2, s. 631, argumentuje pro pozdější dataci Satirikonu.

7 Tac. Ann. 16, 17-19.

8 ROSE, K. F. C. The Petronian Inquisition: An Auto-Da-Fe. Arion: A Journal of Humanities and the Classics, 1966, Vol. 5, No. 3, s. 279. Dostupné na: https://www.jstor.org/stable/20163028.

9 Tac. Ann. 16, 18-19.

10 Tamtéž.

11 DRINKWATER, op. cit., s. 75, 102.

12 Tac. Ann. 16.18-19, DRINKWATER, op. cit., s. 102.

13 VOUT, op. cit., s. 101.

14 CONTE, G. B. Dějiny ř́mské literatury. Překl: BARTOŇKOVÁ, D. Praha: KLP, 2003, s. 410. Dostupné na: https://kramerius5.nkp.cz/uuid/uuid:327dc873-7fa7-4cc1-a39a-336892587c0b.

15 CONTE, op. cit., s. 410-413, CONNORS, op. cit., s. 18.

16 CONNORS, op. cit., s. 18. 
prvky, ${ }^{17}$ a naopak K. F. C. Rose varuje před vnímáním antického díla skrze hodnoty moderní společnosti. ${ }^{18} \mathrm{Z}$ hlediska našeho zkoumání bude i z tohoto důvodu zajímavé vidět, nakolik věrně Satirikon zobrazuje soudobé právní instituty.

Kapitola Hostina u Trimalchiona, nejdelší z dochovaných zlomků a předmět naší pozornosti, se pak nepřekvapivě odehrává v rámci slavnostní večeře u jmenovaného propuštěnce. ${ }^{19}$ Pro kontext si dovolím načrtnout alespoň zběžný obrázek hlavních témat. Samotná hostina je přehlídkou bohatství a triků: chody se spouští ze stropu, ${ }^{20}$ napodobují horoskop ${ }^{21}$ či jsou na místě chytány lovci. ${ }^{22}$ Celá hostina je koncipována jako jedno velké představení, ${ }^{23}$ které má bohatého a váženého Trimalchiona ${ }^{24}$ představit jeho hostům, převážně propuštěncům, v nejlepším světle, avšak opakovaně se jednotlivé scénky zvrtávají. Jednoduchou demonstrací tohoto je scénka, kdy hudebníci předvádějí řeckou hudbu a Trimalchio překládá jejich představení a recituje z antických děl, ${ }^{25}$ avšak klasické př́iběhy plete dohromady hlava nehlava. ${ }^{26}$ Zdalipak tyto rysy mají být vnímány moralisticky či humoristicky, ponechám na čtenáři.

Dalším bodem hodným zřetele je náš vypravěč Encolpius. Večeře se účastní více méně omylem, na hostinu jej upozorní otrok, ${ }^{27}$ a od počátku je z jeho údivu nad hostinou ${ }^{28}$ jasné, že se nejedná o situaci pro něj obvyklou. Bohužel není vždy zcela spolehlivým a objektivním vypravěčem. ${ }^{29}$ Není ani př́liš aktivním narátorem a spíše než hodnocení jednotlivých scén, což by bylo z hlediska jejich ověření jako právních institutů užitečnější, se od něj povětšinou dozvídáme jen jejich popis. Přesto bych jej nenazvala př́mo pasivním deskriptorem, ${ }^{30}$ nebot' určitého hodnocení situace se nám od něj přeci jen občas dostává, ${ }^{31}$ i když možná ne v rozsahu, v jakém bychom jej preferovali.

Pro naše účely je zásadní, že Satirikon byl psán v kontextu principátu, a to do roku 66 n. 1. Přestože dílo samo pojednává o řadě témat z pohledu propuštěnců, jeho autorem je velice pravděpodobně člen smetánky císařské společnosti, Petronius Arbiter. Ke všemu se

17 SANDY, G. - HARRISON, S. Novels ancient and modern. In: WHITMARSH, T. (ed.). The Cambridge Companion to the Greek and Roman Novel. Cambridge: Cambridge University Press, 2008, s. 317.

18 ROSE, op. cit., s. 298.

19 Petr. Sat. 29. V této práci bude zdrojem latinských textů webová stránka Perseus Digital Library (dostupné na: http://data.perseus.org/citations/urn:cts:latinLit:phi0972.phi001.perseus-lat1:1). České překlady včetně vlastních jmen pak pocházejí od Karla Hrdiny, viz PETRONIUS ARBITER. Satirikon: milostné a veselé príhody Encolpia a jeho př́tel za doby Neronovy. Překl.: HRDINA, K. Praha: Svoboda, 1971. Pokud bude použit autorský překlad, tato skutečnost bude na příslušném místě vždy uvedena.

20 Petr. Sat. 60.

21 Petr. Sat. 35.

22 Petr. Sat. 40.

23 ROSATI, G. Trimalchio on Stage. In: HARRISON, S. J. (ed.). Oxford Readings in The Roman Novel. New York: Oxford University Press, 1999, s. 87.

24 Trimalchio je podle všeho členem augustales. Petr. Sat. 30, LAMP, K. S. A City of Marble: The Rhetoric of Augustan Rome. Columbia: University of South Carolina Press, 2013, s. 131.

25 Petr. Sat. 50-52, 58

26 WHITMARSH, T. Class. In: WHITMARSH, T. (ed.). The Cambridge Companion to the Greek and Roman Novel. Cambridge: Cambridge University Press, 2008, s. 79.

27 Petr. Sat. 26.

28 Petr. Sat. 49.

29 WHITMARSH, op. cit., s. 80.

30 CONTE, op. cit., s. 412.

31 Např. Petr. Sat. 70. 
potenciálně jedná o dílo satirického charakteru. Musíme mít tedy na paměti, že text může, ale také nemusí, zobrazovat satirizované vnímání života propuštěnců z pohledu člena císařského dvora spíše než faktickou situaci.

\section{Vstup do otrockého stavu a nabývání otroků}

\section{a) Narození}

V antickém světě existovala řada způsobů, jak se člověk mohl stát otrokem. V této sekci se budeme podrobně věnovat institutům vstupu do otrockého stavu a nabývání otroka v př́padě narození dítěte z matky-otrokyně.

Dítě nenarozené v manželství zásadně přebíralo status své matky. ${ }^{32}$ Existovaly určité výjimky a obzvláště v pozdější době se uplatňovala zásada in favorem libertatis. ${ }^{33}$ Nicméně v základní modalitě se dítě matky-otrokyně samo stávalo otrokem.

Zároveň se v situaci, kdy se narodilo dítě matce-otrokyni a samo se stalo otrokem, rozrostl majetek jejího vlastníka. Klasifikace plodu matky-otrokyně sice byla předmětem sporu starověkých právníků, ale obecně dítě nebylo považováno za fructum, a proto se dítě z matky-otrokyně např́iklad nestávalo majetkem usufruktuáře, nýbrž majetkem vlastníka matky-otrokyně. ${ }^{34}$

A. H. M. Jones uvádí, že v období raného principátu stoupá popularita praxe doma narozených otroků, ${ }^{35}$ tj. otroků narozených z otrokyně, a W. W. Buckland tento způsob vstupu do otrockého stavu považuje dokonce za pravděpodobně nejčastějšśi. ${ }^{36} \mathrm{~V}$ tomto kontextu jistě stojí za povšimnutí i Jonesův postřeh ohledně implicitních nákladů spojených s otroky narozenými doma, jako je např́klad nutnost živit děti v neproduktivním věku. ${ }^{37}$

Př́klad osob narozených do otrockého stavu zřejmě vidíme i v Satirikonu. Actuarius v průběhu večeře předčítá novinky o Trimalchionových državách, a tak se mezi informacemi o hospodářských výsledcích statku u Kum dozvídáme i to, že in praedio Cumano, quod est Trimalchionis, nati sunt pueri XXX, puellae XL (,na statku u Kum, jenž náleží Trimalchionovi, narodilo se 30 hochů a 40 děvčat"). ${ }^{38} \mathrm{Na}$ první pohled není úplně jasné, proč se v kontextu hospodářských výsledků, jakými jsou výnosnost statku či výše odvodů do státní pokladny, ${ }^{39}$ mluví o narozených dětech. Vezmeme-li však v úvahu využití otrocké pracovní síly na velkofarmách v tomto období ${ }^{40}$ spolu s pravděpodobným rozsahem Trimalchionovy farmy u Kum, ${ }^{41}$ zdá se pravděpodobné, že obsahem zprávy je ve skutečnosti informace o počtu nově narozených otroků. ${ }^{42}$

\footnotetext{
32 Gai 1, 55, HEYROVSKÝ, L. Instituce ř́mského práva. Praha: J. Otto, 1894, s. 70. Dostupné na: https:// kramerius5.nkp.cz/uuid/uuid:47fa46ee-9827-46dd-a81f-aff06eac236f.

33 HEYROVSKÝ, op. cit., s. 70.

34 D. 7, 1, 68 (Ulp. 17 ad sab.).

35 JONES, A. H. M. Slavery in the Ancient World. The Economic History Review, 1956, Vol. 9, No. 2, s. 196.

36 BUCKLAND, W. W. The Roman Law of Slavery. Cambridge: Cambridge University Press, 2010, s. 397.

37 JONES, op. cit., s. 193.

38 Petr. Sat. 53.

39 Tamtéž.

40 JONES, op. cit., s. 192.

41 Petr. Sat. 53.

42 Obdobně GARDNER, J. F. Proofs of status in the Roman World. Bulletin of the Institute of Classical Studies, 1986, No. 33, s. 10. Dostupné na: www.jstor.org/stable/43646514.
} 
Zvláštní je uvedený počet celkem sedmdesáti narozených dětí, kdy tento počet by dle předčítané zprávy měl odpovídat dětem narozeným na statku v rámci jednoho dne. ${ }^{43}$ Jelikož v lex Fufia Caninia je maximální celkový počet otroků, ze kterých je počítán maximální počet propustitelných otroků, udáván jako pět set, ${ }^{44}$ zdá se hospodářská jednotka, kde by se při této denní porodnosti narodilo přes dvacet pět tisíc osob ročně, přinejmenším nepravděpodobná. Počet uvedený v Satirikonu by pak svědčil o skutečně neuvěřitelně rozsáhlém hospodářství, kterýžto dojem se jen násobí, pokud budeme uvažovat nejen o hodnotě jednotlivých otroků, ale i o implicitních nákladech spojených s péčí o doma narozené otroky. Je to samozrrejmě jen fiktivní číslo ve fiktivním díle, ale jeho použití v části prríběhu vyzdvihující Trimalchionovo bohatství nás upozorňuje na starověké vnímání zásadní role domácích otroků v kontextu majetku jednotlivce.

Na př́kladu Satirikonu tedy můžeme vidět důležitost institutu narození do otrockého stavu z hlediska ekonomického i právního, jakož i obecný význam otroků pro antické hospodářství.

\section{b) Koupě otroka}

Důležitost otroků z hlediska právního i ekonomického pak ukazuje i další způsob, kterým bylo ve starověkém Římě možno nabýt otroka, a tím je koupě.

Koupě je typem synallagmatické konsensuální smlouvy. ${ }^{45}$ Jelikož byl otrok ve starověku považován za věc, ${ }^{46}$ byl samožrejmě možný i jeho úplatný převod na jiného. Co se hodnoty jednotlivého otroka týká, A. H. M. Jones jako běžnou cenu za dospělého otroka bez zvláštních schopností uvádí částku ve výši 500 až 600 denáriư. ${ }^{47}$

V rámci aedilského ediktu bylo upraveno ručení za vady prodávané věci, a rozsáhlé úpravy se v rámci tohoto institutu dostává právě vadám na otrocích. ${ }^{48}$ Jako i jiné právní instituty prošlo ručení za vady prodávaných otroků svým vývojem, ale v základních rysech existovalo už v době republiky. ${ }^{49}$ Mezi vady otroků rozebírané v Digestech pak patří např́iklad kastrace ${ }^{50}$ či částečná slepota. ${ }^{51}$ Je však třeba upozornit na to, že ručení se neuplatnilo tam, kde vada byla zřejmá již při koupi. ${ }^{52}$ Prakticky měl prodejce podle aedilského ediktu povinnost upozornit kupce na vady, patřící do určitých skupin, nebo prŕípadně mohl prodejce přislíbit specifické vlastnosti prodávané věci. ${ }^{53}$ Vidíme tedy, že zdravotní stav a určité vlastnosti otroků hrály ve starověku natolik důležitou roli, že si zasloužily zvláštní právní ochranu.

\footnotetext{
43 Petr. Sat. 53

44 Gai 1, 43, viz diskuze k lex Fufia Caninia níže v sekci Manumissio testamento.

45 SOMMER, O. Učebnice soukromého práva řimského. Díl 2: Právo majetkové. Praha: nákl. vl., 1935, s. 55. Dostupné na: https://kramerius5.nkp.cz/uuid/uuid:ff6438d0-9e62-11e5-a7d7-005056827e52.

46 Gai 2,14a, viz diskuze výše v úvodu.

47 JONES, op. cit., s. 194.

48 D. 21, 1, 1 (Ulp. 1 ad ed. aedil. curul.).

49 HUGHES, L. A. The Proclamation of Non-Defective Slaves and the Curule Aediles' Edict. Ancient Society, 2006, Vol. 36, s. 249.

50 D. 21, 1, 6, 2 (Ulp. 1 ad ed. aedil. curul.).

51 D. 21, 1, 4 (Ulp. 1 ad ed. aedil. curul.).

52 D. 21, 1, 1, 6 (Ulp. 1 ad ed. aedil. curul.).

53 D. 21, 1, 1, 1 (Ulp. 1 ad ed. aedil. curul.).
} 
Mezi koupené otroky patří i sám Trimalchio. Není to okolnost, kterou by se pokoušel jakkoliv skrývat, naopak se to pro něj zdá být předmětem pýchy. Vždyt' tématem dekorace na stěně hned po vstupu do jeho domu je namísto obvyklých mytologických témat zobrazení Trimalchiona s dlouhými vlasy na trhu s otroky. ${ }^{54}$ Detaily o průběhu samotné koupě bohužel neznáme, a ani o jeho vstupu do otrockého stavu toho mnoho nevíme. Trimalchio ř́ká, že nebyl vyšší než svícen, když přišel do domu svého pána. ${ }^{55}$ Dále uvádí, že přišel z Asie, ${ }^{56}$ což G. Bagnani chápe jako římskou senátorskou provincii Asie. ${ }^{57}$ Nakonec od Trimalchiona ještě víme, že je dnes prý bohatší než celé jeho rodiště. $58 \mathrm{Z}$ textu tedy vyplývá jen to, že Trimalchio, dnešní boháč, byl svým pánem zakoupen na trhu s otroky ještě $v$ dětském věku.

Další z otroků, o jejichž koupi se v rámci Satirikonu dozvídáme, je Habbinův otrok. ${ }^{59}$ O jeho původu nic nevíme, máme však o něco více informací o jeho koupi. Byl zakoupen za 300 denárů, a tuto částku jeho vlastník považuje za nízkou cenu za otroka. ${ }^{60} \mathrm{I}$ v kontextu Jonesovy studie se tato cena jeví velice nízkou. Na druhou stranu se ale Jonesova studie věnuje dospělým otrokům. Habbinův otrok však v době koupě zřejmě nebyl dospělý, nebot' byl svým pánem posléze posílán na vzdělání na trh místo do škol. ${ }^{61}$ Avšak takto nízká cena má i další potenciální důvod - otrok silně šilhá, což bychom v kontextu diskuse antických právníků o vadách kupovaných otroků, mezi něž patřilo i horší zrakové postižení, mohli vnímat jako nežádoucí. Šilhání sice nebylo problémem, který by jednak pro svou závažnost a jednak pro svou zřejmost způsobil vadu z hlediska aedilského ediktu. Ale pokud použijeme aedilský edikt jako indikaci typů problémových zdravotních stavů, které pravděpodobně ovlivňovaly poptávku po jednotlivých otrocích, šilhání by mohlo takto nízkou cenu vysvětlovat.

V tomto bodě je však možné ilustrovat roli subjektivních preferencí a potřeb v rámci koupě. Pro Habbinu šilhání není žádný zásadní problém. ${ }^{62}$ Oproti tomu Habbinas považuje za podstatné nedostatky svého otroka to, že chrápe a že je obřezaný. ${ }^{63}$ Jako pozitivní vlastnosti otroka naopak Habbinas uvádí jeho alternativní formu vzdělání, díky které otrok umí trhové písně, a jeho všestrannou zručnost. ${ }^{64}$ Vidíme tedy, že jakkoliv aedilský edikt může indikovat obecně ceněné vlastnosti otroků, nemůže postihnout všechny životní situace. Individuální poptávka kupujících tak nakonec mohla indikovat zcela jiné osudy individuálních otroků, než jaké bychom na základě právní úpravy ručení za vady předpokládali.

Můžeme tedy shrnout, že v případě koupě je zásadní pojetí otroka jako věci. Na př́ikladu Satirikonu vidíme geografické rozpětí starověkého obchodu s otroky i variabilitu

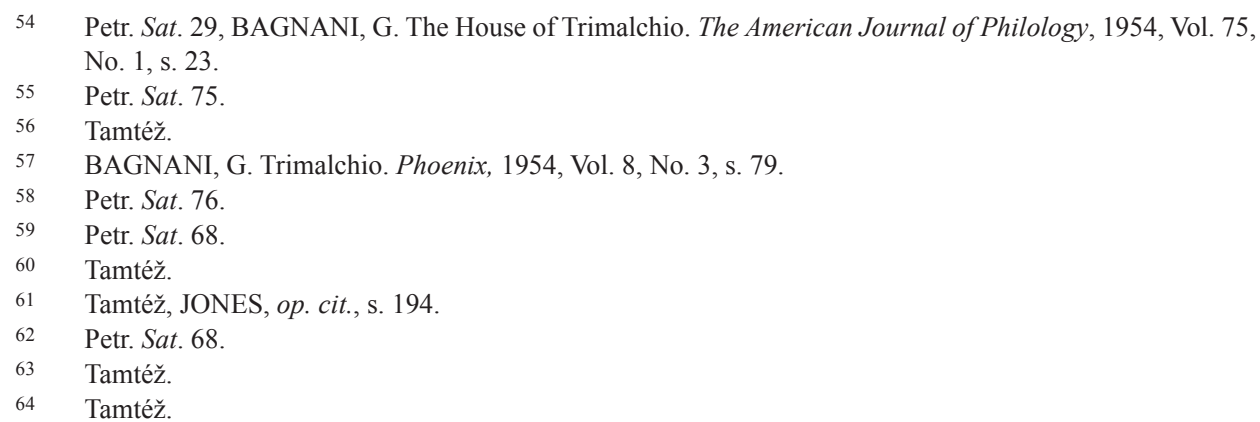


následných osudů zakoupených otroků. Z hlediska ekonomické důležitosti otroků pak bylo podstatné, že římské právo zakotvovalo institut odpovědnosti za vady otroků. Na druhou stranu však realitu obchodu a faktickou žádanost jednotlivého otroka určovala individuální potřeba daného kupujícího.

\section{c) Dobrovolný vstup do otrockého stavu}

V této sekci se blíže podíváme na aspekt vůle jednotlivce v kontextu vstupu do otroctví skrze institut koupě. Specificky se zaměříme na volbu jednotlivce stát se otrokem, obvykle nazývanou dobrovolný prodej svobodného. ${ }^{65}$

Právní úprava se, co se týče dospělých svobodných osob, soustředí na podvodný vstup do otrockého stavu skrze institut koupě, obzvláště v návaznosti na pozdější spory o svobodu takto fradulentně prodaných jedinců. ${ }^{66}$ Dle rrímskoprávní úpravy, pokud se svobodný člověk dobrovolně za účelem zisku nechal prodat do otroctví, nemohl posléze v soudním procesu uplatnit svůj nárok na svobodu ${ }^{67}$ a v konečném důsledku se tak stal otrokem. ${ }^{68}$ W. W. Buckland uvádí, že tento institut prošel vývojem v rámci římské historie, ale v základních rysech jej podle něj znalo již období republiky. ${ }^{69}$ Zásadní je tedy z hlediska dochované právní úpravy motiv zisku.

Možných variant motivace $\mathrm{k}$ dobrovolnému vstupu do otroctví však může být více, patří mezi ně například i to, že otroctví bylo jedním z podstatných nástrojů sociální mobility starověkého světa. ${ }^{70} \mathrm{~V}$ př́ípadě splnění určitých podmínek s sebou propuštění z otroctví přinášelo zisk římského občanství pro propuštěnce. ${ }^{71} \mathrm{D}$. B. Martin pak vnímá i samotné otroctví jako formu sociální mobility v rámci antického patronátního systému - podle něj v rámci otrocké služby mohl jednotlivec nabýt společenský status skrze asociaci se svým pánem či ve spojení se svou funkcí v rámci císařské administrativy. ${ }^{72}$ Přístup k této formě sociální mobility však nutně závisel mimo jiné na typu otroka i na společenském postavení jeho pána. ${ }^{73}$

Dalším důvodem pro dobrovolný vstup do otroctví mohlo být i využití tohoto institutu pro útěk z problematické ekonomické situace. V antice dobře známe institut prodeje

65 W. W. Buckland uvádí názor, že analogicky by se ustanovení o fradulentním prodeji tohoto typu aplikovala i na ostatní formy nabývání, nicméně zde se pro jednoduchost budeme držet institutu prodeje. BUCKLAND, op. cit., s. 429.

66 D. 1, 5, 5, 1 (Marci. 1 inst.).

67 D. 1, 5, 21 (Modest. 7 reg.), BUCKLAND, op. cit., s. 428.

68 BUCKLAND, op. cit., s. 430-431.

69 W. W. BUCKLAND, op. cit., s. 433, obdobně SILVER, M. Places for Self-Selling in Ulpian, Plautus and Horace: The Role of Vertumnus. Mnemosyne, 2014, Vol. 67, Fasc. 4, s. 579.

70 HORDEN, P. - PURCELL, N. The Corrupting Sea: a study of Mediterranean history. Singapore: Blackwell Publishing, 2000, s. 388, MARTIN, D. B. Slavery as Salvation. Haven - London: Yale University Press, 1990, s. 48, GARNSEY, P. et al. The Social Hierarchy. In: GARNSEY, P. - SALLER, R. - ELSNER, J. - GOODMAN, M. - GORDON, R. - WOOLF, G. (eds.). The Roman Empire: Economy, Society and Culture. Berkeley: University of California Press, 2015, s. 146. Dostupné na: https://www.jstor.org /stable/10.1525/j.ctt9qh25h.15.

71 Gai 1, 12.

72 MARTIN, op. cit., s. 48.

73 MARTIN, op. cit., s. 48-49. 
svobodných dětí rodiči v případech nepříznivé daňové situace ${ }^{74}$ či prímo pro zadluženost jako takovou. ${ }^{75}$ Analogicky by tak bylo možné očekávat obdobnou motivaci pro vstup do otroctví i u dospělých.

Mezi prezentací a realitou dobrovolného vstupu svobodných dospělých osob do otroctví ve starověkém Ř́mě nacházíme určitý rozpor. A. Rio ve své studii upozorňuje, že přestože byla rétorika právní úpravy vůči institutu dobrovolného otroctví silně negativně zabarvena, fakticky institut dobrovolného prodeje do otroctví umožňovala. ${ }^{76} \mathrm{~A}$. Rio i P. Horden argumentují pro dobrovolné otroctví jako numericky nedostatečně reprezentovaný aspekt antického otroctví. ${ }^{77}$

Institut dobrovolného vstupu do otroctví můžeme zkoumat i na příkladu Satirikonu. Dobrovolné otroctví je zde sice zmíněno v kontextu hádky, ale tvrzení se vyskytuje opakovaně a zdá se být myšleno vážně. ${ }^{78}$ Trimalchionův propuštěnec o sobě již na začátku svého proslovu prrímo říká, že se dobrovolně stal otrokem. ${ }^{79}$ Po popisu svých životních osudů se pak k tomuto tématu vrací $\mathrm{s}$ tím, že panovala obecná nejistota o jeho osobním stavu. ${ }^{80}$ Sám však o sobě v průběhu vyprávění mluví jako o otrokovi a později jako o propuštěnci. ${ }^{81}$ Zřejmě se tedy skutečně jedná o dobrovolný vstup do otroctví.

Motivací Trimalchionova propuštěnce pro vstup do otroctví však nemůže být fradulentní obchod ve smyslu snahy získat zisk z prodeje a posléze se znovu urychleně dostat na svobodu. O profitu z prodeje není v textu nic zmíněno. Ani o snaze dovolat se svobody se z textu nedozvídáme. Víme jen, že dotyčný byl manumitován až po čtyřiceti letech služby u Trimalchiona. ${ }^{82}$ Zdá se, že se tedy nejedná o typický př́iběh podvodného obchodu s takovou motivací, jakou známe z Digest. ${ }^{83}$

Nezbývá nám nic jiného než zvážit propuštěncova slova ohledně motivace. Sám říká quia ipse me dedi in servitutem et malui civis Romanus esse quam tributarius (protože jsem se sám dal do otroctví a chtěl raději být římským občanem než tributarius) ${ }^{84} \mathrm{~A}$. Rio jako účel tohoto vstupu do otroctví vnímá právě zisk římského občanství. ${ }^{85}$ Osobně se však pozastavuji nad původním statusem propuštěnce. Tributarius je podle všeho někdo, kdo má platit tributum, tedy daň. ${ }^{86}$ Pokud si představíme 40 let trvající otrocký stav, zdá se mi pravděpodobnější okamžitou motivací v době dobrovolného vstupu do otroctví právě únik před ekonomickými faktory spojenými s původním statusem spíše než motivace sociální mobilitou ve smyslu snahy o zisk rrímského občanství.

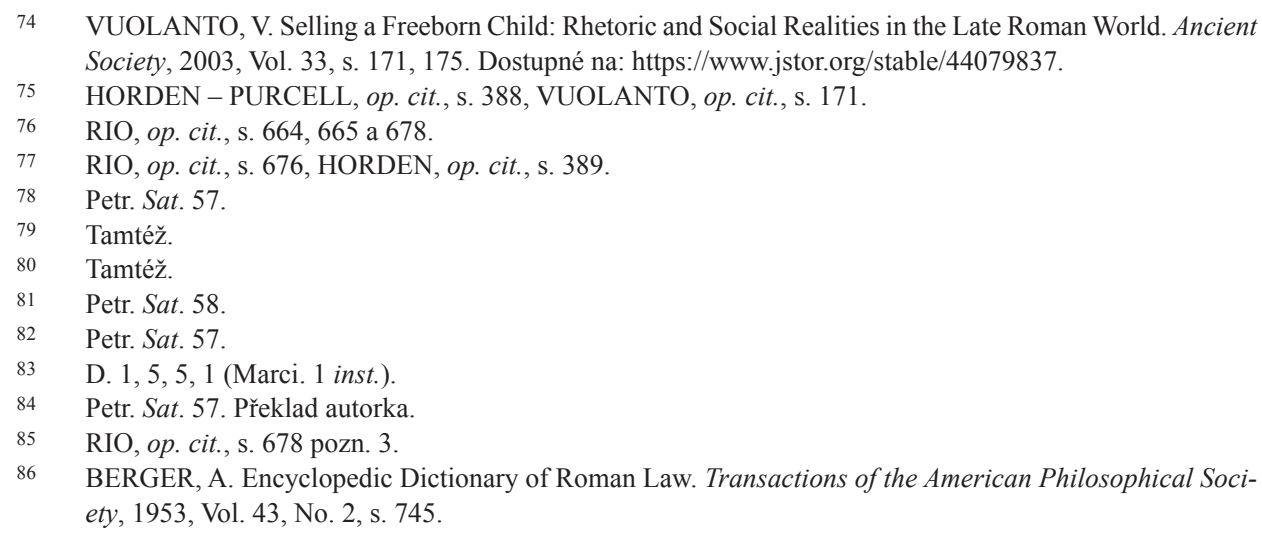


Př́ipad Trimalchionova propuštěnce tedy indikuje myslitelnost dobrovolného prodeje svobodného člověka do otroctví, minimálně pak ve fiktivním příběhu. Na rozdíl od případů uváděných v Digestech se jeho důvodem nezdá být čistý zisk. Pravděpodobná je motivace bud' možností sociální mobility, anebo nutností ekonomického úniku z předchozího statusu tributaria. Z hlediska jeho osobního postavení po dobu trvání otroctví je patrná určitá nejistota, i když on sám se v průběhu tohoto času považoval za otroka a posléze za propuštěnce. Celkově se tedy institut dobrovolného vstupu do otroctví mezi ostatními variantami nabývání otroků a vstupu do otroctví zde probíranými vyznačuje vyšší mírou svobodné volby dotčeného jedince. Ukazuje také, že alespoň pro některé jednotlivce mohlo otroctví být relevantní variantou řešení jejich životních situací.

\section{Manumissio}

\section{d) Manumissio inter amicos}

V druhé části této práce se budeme zabývat jedním z velkých témat Hostiny u Trimalchiona, a tím je osvobození otroků. Propuštění otroka mělo za následek změnu v jeho osobním statusu, z otroka se stával svobodný člověk. ${ }^{87} \mathrm{~V}$ kontextu propouštění otroka bychom zřejmě očekávali rozhodující roli vlastníka otroka, avšak moderní autoři poukazují na možnosti iniciativy ze strany otroka v rámci tohoto procesu. Dále se tato studie věnuje institutu manumissio inter amicos a porovnání moderních představ o možnostech iniciativy otroka $\mathrm{s}$ jeho rolí zobrazenou v Satirikonu.

Manumissio inter amicos je př́kladem neformálního typu manumisse inter vivos. ${ }^{88}$ O detailním průběhu a náležitostech tohoto typu manumisse nemáme přesné zprávy, ale ve svém jádru se jedná o veřejný neformální projev vůle pána propustit otroka. ${ }^{89}$ Jelikož se jednalo o neformální způsob propouštění, jeho výsledkem bylo u otroků takto manumitovaných získání statusu Latini Iuniani na základě lex Iunia. ${ }^{90}$ Pokud chtěl takovýto propuštěnec získat římské občanství a všechny z něj plynoucí výhody, mohl toho dosáhnout bud' opakovaným propuštěním (podle civilního práva) od svého bývalého pána, ${ }^{91}$ či jej za specifických podmínek mohl získat od samotného státu. ${ }^{92}$

R. Scholl pak i z hlediska motivace k propuštění zkoumal tři dochované epigrafické záznamy o manumissio inter amicos z období 3. stol. n. 1., a poukazuje na to, že se tyto záznamy řídí určitými zvyklostmi - jedná se např́klad o uvedení informace o obdržení sumy od třetí osoby za účelem propuštění. ${ }^{93}$ Upozorňuje však na častý výskyt upřesnění vztahu mezi propouštěným a třetí osobou v návaznosti na tento dar, kdy poskytnutí daru

88 ROTH, U. Peculium, Freedom, Citizenship: Golden Triangle or Vicious Circle? An Act in Two Parts. Bulletin of the Institute of Classical Studies. Supplement. 2010, No. 109, s. 106-107. Dostupné na: https://www .jstor.org/stable/44215126.

89 BUCKLAND, op. cit., s. 548.

90 Gai 1, 22, BUCKLAND, op. cit., s. 533, HEYROVSKÝ, op. cit., s. 76.

91 Gai 1, 35 .

92 Gai 1, 29-34.

93 SCHOLL, R. „Freilassung unter Freunden“ im römischen Ägypten. In: BELLEN, H. - HEINEN, H. (eds.). Fünfig jahre Forschungen zur antiken Sklaverei an der Mainzer Akademie 1950-2000. Stuttgart: Steiner, 2001, s. 166. K manumisní sumě např. v případě chr.mitt.362 bylo poskytnuto 2200 drachem. Tamtéž, s. 159 .
} 
mezi nimi nevyvolává žádný závazek. ${ }^{94}$ Zajímavé je také to, že sumu jako takovou R. Scholl vnímá v kontextu možnosti pána pořídit si náhradu za propouštěného. ${ }^{95}$ Ohledně manumissní částky, jakož i jejího původu a funkce, však nepanuje konsensus. ${ }^{96}$ U. Roth tak např́íklad vnímá manumissní částku jako další obchodní artikl římské doby - podle ní byla poskytována otrokem z peculia a mohla pána motivovat k propuštění otroka, obzvláště ve vztahu k Latini Iuniani. ${ }^{97}$ Obě dvě formy této úvahy naznačují možnost ekonomické motivace pána $\mathrm{v}$ procesu manumisse a možnost aktivní role otroka $\mathrm{v}$ rámci procesu propouštění.

Z hlediska otrokovy role $\mathrm{v}$ rámci propouštění je také zajímavý koncept otroka, který si své propuštění může zasloužit. ${ }^{98} \mathrm{~V}$ tomto duchu pak římské právo znalo např́iklad institut propuštění otroka, který pomohl k dopadení vraha svého pána, ${ }^{99}$ i když zde je možné debatovat i o dalších možných funkcích tohoto institutu. T. E. J. Wiedemann pak důležitost konceptu otroka zaslouživšího si propuštění vnímá spíše na rétorické úrovni, kdy podle něj je jejím účelem spíše motivace otroků a zdůvodnění trvajícího společenského uspořádání, než že by se jednalo o fakticky používané kritérium pro propouštění jednotlivých otroků. ${ }^{100}$

V průběhu hostiny u Trimalchiona jsme svědky dvou faktických manumissí otroků, jakož i fiktivní manumisse prasete. $Z$ důvodu limitovaného rozsahu této práce ponecháme stranou scénu s prasetem a jeho osvobození101 a podíváme se pouze na propouštění otroků.

První z otroků propuštěných formou inter amicos je otrok znázorňující Baccha. Jeho př́íklad skutečně svědčí o naprostém minimu požadavků na propuštění otroka touto formou. Ve scénce otrok roznáší hostům na hostině víno a přednáší verše svého pána, $v$ tom se ale Trimalchio otočí a následuje text: Trimalchio: „,Dionyse, “ inquit ,, liber esto. “ („Trimalchio řekl: ,Dionýse, budiž svobodný'“"). ${ }^{102}$ Otrok si nasazuje čepku pilleus, která symbolizuje propuštění, ${ }^{103}$ a děj volně pokračuje. Pro formální následky manumissio inter amicos, zdá se, tato forma zcela dostačuje. Co se propouštěcího rozkazu týká, U. Roth zde upozorňuje na identickou formulaci příkazu jako u propouštěcího př́íkazu v manumissio testamento podle Gaia. ${ }^{104}$ Nicméně absence samotné formulace propouštěcího př́kazu v následující scénce neformálního propuštění nám bohužel nedovoluje dělat širší závěry ohledně podstatnosti této specifické formulace pro manumissio inter amicos obecně.

$\mathrm{V}$ porovnání $\mathrm{s}$ moderními názory ohledně role otroka $\mathrm{v}$ rámci procesu propuštění je na samotné scénce patrná absence jakékoliv aktivity ze strany otroka. Nenacházíme zde žádnou zmínku o manumissní sumě a propuštění samotné není jakkoliv odůvodněno. Idea

94 Tamtéž, s. 168.

95 Tamtéž, s. 168.

96 ROTH, Peculium, s. 92-104.

97 ROTH, Peculium, s. 104-105.

98 WIEDEMANN, T. E. J. The Regularity of Manumission at Rome. The Classical Quarterly, 1985, Vol. 35, No. 1, s. 175. Dostupné na: https://www.jstor.org/stable/638813.

99 HEYROVSKÝ, op. cit., s. 79.

100 WIEDEMANN, op. cit., s. 175.

101 Odkazuji na článek ROTH, Liberating the cena, v němž se na stranách 616-618 rozebírá scénka manumisse prasete, a pro porovnání pak na zbytek článku pro diskuzi o všech třech manumissio inter amicos.

102 Petr. Sat. 41. Přklad autorka.

103 BERGER, op. cit., s. 631.

104 ROTH, Liberating the cena, s. 618, Gai 2, 267. 
zásluhy otroka není zmíněna ani na rétorické úrovni. Propuštění jako takové jistě může být výsledkem delšího procesu, nicméně scénka tak, jak ji máme popsánu v Satirikonu, ukazuje na absolutní libovůli pána a nenaznačuje nic o možné aktivní roli otroka v tomto procesu.

I u druhého z otroků propuštěných formou inter amicos, člena skupiny trapézistů, ${ }^{105}$ je popis propuštění velmi strohý. Autor nám neposkytuje detaily samotného aktu propuštění. Kontextuálně se jedná o představení jakýchsi otroků-akrobatů, v rámci něhož jeden z nich upadne a zraní Trimalchiona. Trimalchio následně, v reakci na trapézistovy prosby, reaguje takto: in vicem enim poenae venit decretum Trimalchionis, quo puerum iussit liberum esse, ne quis posset dicere tantum virum esse a servo vulneratum („,místo trestu přišlo od Trimalchiona rozhodnutí, jímž propustil tohoto otroka na svobodu, aby nikdo nemohl říci, že muž tak veliký byl poraněn otrokem“). ${ }^{106}$

Opět se tedy nejedná o rozhodnutí na základě meritu nebo, pokud nám scénka dovoluje posoudit, finančně motivované. Je zde určitá iniciativa otroka, která však spočívá pouze v prosbě o milost. Faktické rozhodnutí, zda jej propustit, je pouze na Trimalchionovi. A ten tak nečiní na základě zásady otrokových zásluh, nýbrž spíše v přímém rozporu s touto zásadou. Jelikož byl otrok nešikovný a uklouzl, byl propuštěn.

Celkově nám tedy př́íklady manumisse v Satirikonu neukazují otroky v aktivní roli v procesu propouštění. Nejsou ani v souladu s ideou otroka, který si propuštění zaslouží, ba můžeme polemizovat i o antagonizaci tohoto konceptu v př́padě trapézisty. Ze všeho nejvíce se však tyto př́ípady zdají být projevem absolutní moci Trimalchiona.

Obě scénky nám také naznačují, že manumissio inter amicos byla skutečně neformálním jednáním. Bohužel přesné znění projevu Trimalchionovy vůle osvobodit otroka známe pouze $\mathrm{v}$ jednom případě a nemůžeme tak činit obecné závěry o podobě vyjádření vůle otroka propustit.

\section{e) Manumissio testamento}

V této sekci se budeme věnovat propouštění formou závěti a podíváme se na Satirikon i jako potenciální zdroj informací o daňové povinnosti. Pro účely diskuze o proaktivní roli otroka z hlediska tohoto typu manumisse nadále vycházím z teorií uvedených v sekci Manumissio inter amicos. ${ }^{107}$

Př́íkladem formálního způsobu propouštění je manumissio testamento ${ }^{108}$ - formou závěti -, který vedl k zisku římského občanství. ${ }^{109} \mathrm{O}$ tomto typu manumisse se někteří autoři domnívají, že byla vůbec nejčastější formou propouštění otroků ve starověku. ${ }^{110}$ I lex Fufia Caninia by tomuto závěru mohl nasvědčovat, nebot' se jednalo o opatření omezující množství otroků propouštěných závětí. ${ }^{111}$ Povolené množství propustitelných otroků

\footnotetext{
105 Petr. Sat. 54.

106 Tamtéž.

107 Specificky se jedná o roli rétoriky meritu otroka dle T. E. J. Wiedemanna a o roli summa manumissoria dle A. Rio a R. Scholla, jak již bylo rozebráno výše.

108 ROTH, Peculium, s. 107.

109 ROTH, Peculium, s. 107, BUCKLAND, op. cit., s. 439.

110 BUCKLAND, op. cit., s. 546.

111 Gai 1, 43, WIEDEMANN, op. cit., s. 168. T. E. J. Wiedemann zde ovšem upozorňuje i na problematiku dichotomie domnělé a skutečné potřeby právní úpravy ve vztahu k hodnocení frekvence využití jednotlivých typů manumisse na základě jejich regulace.
} 
bylo odstupňováno podle celkového množství otroků vlastněných zůstavitelem. Tyto specifikace se netýkaly osob vlastnících méně než dva otroky, ale např́iklad pro osoby vlastnící dva až deset otroků byla stanovena možnost propustit z nich až polovinu a pro osoby vlastnící více jak sto a méně než pět set otroků činil maximální poměr propustitelných otroků jednu pětinu. ${ }^{112}$

Požadavků pro platnost závěti ve starověkém Římě existovalo vícero. Lišily se podle typů závěti, které původně byly tři, z nichž v době Gaiově už pak přežíval pouze typ per aes et libram. ${ }^{113}$ Pro tento způsob pořízení závěti se používal proces fingovaného prodeje a byla nutná přítomnost pěti svědků. ${ }^{114}$ Mezi další náležitosti patřily např́iklad testovací způsobilost zůstavitele, ${ }^{115}$ ustanovení dědice formálním způsobem ${ }^{116}$ a neopomenutí nepominutelných dědiců. ${ }^{117}$ Jako zajímavost je možné zmínit i to, že zůstavitel mohl svým dědicem ustanovit závětí propuštěného otroka. ${ }^{118}$

Se všemi typy propouštění, a tedy i s manumissio testamento, byly spojeny určité veřejnoprávní povinnosti. Mezi ně patřila i vicesima manumissionum. Byla to daňová povinnost ve výši jedné dvacetiny hodnoty osvobozeného otroka, založená ustanoveními lex Manlia. ${ }^{119}$ Detaily o tom, kdo byl faktickým plátcem této daně, nejsou vyjasněné, nicméně někteří autoři se domnívají, že obecně dopadala povinnost zaplatit tuto daň právě na propuštěného otroka. ${ }^{120}$

V závěru hostiny v Satirikonu Trimalchio oznamuje svůj záměr osvobodit otroky závětí - doslova omnes illos in testamento meo manu mitto (,ve své závěti propouštím ony všechny /otroky/“") $)^{121}$ - a své tvrzení dokládá závětí, ze které předčítá. ${ }^{122} \mathrm{O}$ specifických aspektech již dříve sepsané závěti se z textu nic nedozvídáme. Vzhledem k tomu, že dědičkou Trimalchio výslovně ustanovuje svou manželku, nejedná se v př́padě otroků o jejich propuštění a ustanovení dědicem. ${ }^{123}$ Můžeme však hodnotit soulad závěti s lex Fufia Caninia. Z kontextu vyplývá, že propuštění ze závěti se má týkat otroků již dřive přizvaných ke stolu. Jsou jimi Filargyros a Cario. ${ }^{124}$ Nejedná se však o Filargyrovu družku, která sice byla také přizvaná ke stolu, nicméně jí se propuštění v závěti nemohlo týkat, nebot' závětí je naopak odkázána Filargyrovi. ${ }^{125}$ Vzhledem k předpokládanému vysokému počtu otroků v Trimalchiově vlastnictví, jež dovozuji jednak z hospodářské zprávy zmíněné výše

\footnotetext{
112 Gai $1,43$.

113 Gai 2, 103 .

114 Gai 2, 104

115 Gai 2, 113 .

116 Gai 2, 117.

117 Gai 2, 123.

118 Gai 2, 153.

119 BECK, Ch. The Age of Petronius Arbiter. Memoirs of the American Academy of Arts and Sciences, 1857 , Vol. 6, No. 1, s. 85 .

120 BECK, op. cit., s. 86, KLEIJWEGT, M. Cum Vincensimariis Magnam Mantissam Habet (Petronius Satyricon 65.10). The American Journal of Philology, 2002, Vol. 123, No. 2, s. 280. Dostupné na: https://www .jstor.org/stable/1561744, k opačnému názoru např. BERGER, op. cit., s. 764. Petr. Sat. 71. Překlad autorka.

Tamtéž.

Ve smyslu Gai 2, 153.

Petr. Sat. 70-71.

Petr. Sat. 71.
} 
a jednak z množství otroků figurujícím v rámci celé večeře, by propuštění dvou otroků bylo v souladu s požadavky lex Fufia Caninia.

V rámci diskuze o závěti se dozvídáme informace i o již zmíněné daňové povinnosti. Trimalchio v závěti odkazuje Filargyrovi i Carionovi určité věci. Tak odkazuje Carioni quoque insulam et vicesimam et lectum stratum („Carionovi nájemní dům, peníze na splacení propuštěnecké daně a všecko zařízeníc). ${ }^{126}$ Oproti tomu: Philargyro etiam fundum lego et contubernalem suam („Filargyrovi odkazuji taky pozemek a jeho družku-otrokyni“"). ${ }^{127}$ Oba tedy dostávají určité věci potenciální výdělečné hodnoty. Nádavkem pak Filargyros dostává ještě svoji contubernalem a Cario vicesimam. Zdá se tedy skutečně, že v tomto př́padě je spíše jako zvláštnost, v souladu s pohledem M. Kleijwegta, ${ }^{128}$ vicesimam udělena Carionovi. Z kontextu je toto možno vnímat jako určité vyrovnání obou propouštěných otroků spíše než jako zvláštní dobrodiní projevené Carionovi - vždyt' Filargyros sice nedostává vicesimam, ale dostává svou partnerku.

Od Trimalchiona se také dozvídáme, co si máme myslet jak o jeho motivaci k samotné manumissi otroků, tak i o jeho motivaci $\mathrm{k}$ veřejnému ohlášení tohoto záměru. Co se ohlášení týká, říká k němu následující: Et haec ideo omnia publico, ut familia mea iam nunc sic me amet tanquam mortuum (,A to všechno oznamuji proto, aby mě čeled’ měla už nyní tak ráda, jako kdybych byl mrtev"). ${ }^{129}$ Samotnému propuštění, zdá se, dominují humanitární důvody. Trimalchio o otrocích ř́ká, že et servi homines sunt ... etiam si illos malus fatus oppressit („,otroci jsou taky lidé ... třebaže je zlý osud ponížil“). ${ }^{130}$ Tento propuštěnec své otroky propouští ze sympatie s jejich osudem. Pro moderní teorie o aktivní roli otroků zde však mnoho důkazů nenajdeme. $V$ rámci celé scénky nám není sdělen detailnější důvod propuštění těchto otroků. Není zde ani zmínka o tom, že by si specificky tito dva otroci propuštění zasloužili v porovnání s ostatními otroky v Trimalchionově domácnosti. Nevidíme zde také žádnou iniciativu ze strany otroků. Celé propouštění je důsledkem aktivity a rozhodnutí jediného muže, a to právě Trimalchiona.

Porovnáním obou typů manumissí v Satirikonu pronikají na povrch určité rozdílnosti mezi nimi. Použití formy manumissio inter amicos se zdá být lepší pro spontánní situace v Satirikonu jsou scény s tímto typem manumisse méně promyšlené, např́íklad propuštění trapézisty je reakcí na zranění Trimalchiona v důsledku nehody. ${ }^{131}$ Naopak použití formy manumissio testamento se v Satirikonu zdá být mnohem plánovanější. V době hostiny je závět' již sepsaná, a její dlouhodobé důsledky jsou analyzované. ${ }^{132}$ Srovnáním manumissí v Satirikonu tedy získáváme lepší představu o možném využití obou forem propuštění.

Manumisse otroků závětí v Satirikonu tedy poukazuje na to, že propuštění otroka ve starověkém Římě mělo dalekosáhlé důsledky. Poskytuje nám tak například svědectví o daňovém břemeni souvisejícím s propuštěním otroka, které zřejmě skutečně postihovalo propouštěného. Ve srovnání s moderním nahlížením nám však tato epizoda v Satirikonu neposkytuje informace o iniciativě propouštěných otroků, ale naopak opět vyzdvihuje

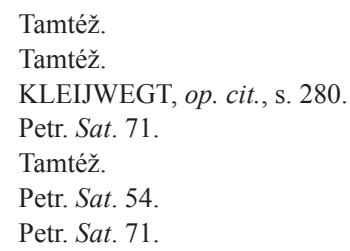


absolutní moc pána. Naopak znalost právních institutů nám pomáhá hodnotit jednotlivé scény Satirikonu z hlediska jejich souladu s právním pořádkem.

\section{Vývoj forem manumisse a role otroků ve společenském pořádku}

V této sekci se opět vrátíme k tématu vzájemné přínosnosti Satirikonu a právní vědy. Na př́kladu Satirikonu totiž můžeme vidět i vývoj forem manumisse, což je relevantní pro otázku datace Satirikonu a pro vnímání role otroků v rámci římské společnosti v období raného principátu.

V souvislosti se sociálním pořádkem je pro dobu na počátku principátu vhodné připomenout převraty pozdní republiky, které se výrazně dotkly i společenské hierarchie. ${ }^{133}$ V rámci tohoto kontextu je pak třeba vnímat početnou a ekonomicky podstatnou část populace představovanou otroky, jejichž společenské postavení bylo na samotné spodní hranici sociální hierarchie římského státu. ${ }^{134}$ A tak není divu, že se určité starověké pohledy snažily s touto dichotomií pracovat. U Columelly i u Seneky tak nalezneme rady ohledně humánního zacházení s otroky, jednak za účelem zlepšení jejich produktivity, ${ }^{135}$ jednak také za účelem předcházení jejich nepřátelství. ${ }^{136}$ Mezi př́klady humánního zacházení s otroky pak u Seneky nalezneme právě hodování s otroky. ${ }^{137}$

Přesně to však patři i mezi právní instituty, a to mezi pozdější varianty propouštění otroků inter vivos. Tato neformální metoda se nazývala manumissio per mensam. Ve své podstatě se při tomto způsobu manumisse jednalo o propuštění formou přizvání otroka ke stolu v rámci hostiny, zřejmě spojené s nějakou listinou toto potvrzující. ${ }^{138}$

I v rámci Satirikonu nalezneme pasáž, v níž jsou otroci přizváni ke stolu v rámci hostiny. ${ }^{139}$ Důsledek tohoto pozvání je však velmi rozdílný od manumissio per mensam. Jednoznačně nemá žádné dopady na osobní stav přizvaných otroků. Právě naopak, teprve ve scénce následující po přizvání otroků ke stolu Trimalchio těmto konkrétním otrokům slibuje manumissio testamento a výslovně uvádí specifika jejich propuštění, které jsme probírali již výše. ${ }^{140} \mathrm{~V}$ tomto období tedy i na př́kladu Satirikonu můžeme vidět, že přizvání otroků ke stolu bez dalšího skutečně nemá žádné právní důsledky.

Faktickou motivací Trimalchiona k přizvání otroků ke stolu tedy není jejich propuštění. Ze všeho nejvíce scénka připomíná právě ideu o „managementu“ otroků prezentovanou v pracích Columelly a Seneky. Trimalchio sám říká et servi homines sunt („,i otroci jsou lidéc). ${ }^{141}$

V kontextu rozjívenosti celé scény ${ }^{142}$ však tento prezentovaný postoj nemá na prŕítomnou společnost nikterak pozitivní dopady. V našem vypravěči Encolpiovi celá situace vyvolává překvapení a nechut'. Těsně před přizváním, proloženo jen scénkou s omýváním

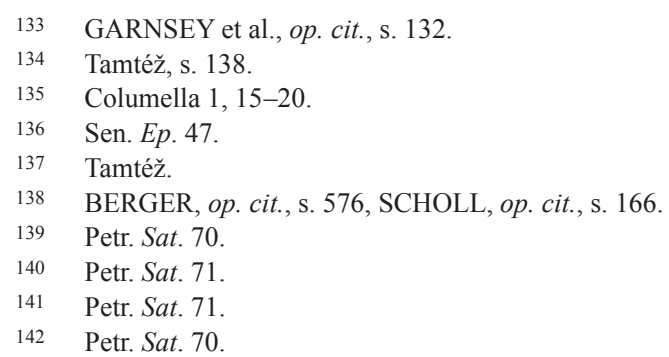


nohou, Encolpius dokonce přiznává stud nad následujícím vyprávěním, ${ }^{143}$ což je v kontextu celého Satirikonu jistě pozoruhodné. Jeho celkový dojem je ten, že následkem přizvání dochází k naprostému chaosu - hosté jsou málem shozeni z lehátek a ve vřavě se vmžiku kuchař sází se svým pánem ohledně výsledků závodů vozatajů. ${ }^{144}$ Zdá se to být vhodnou alegorií pro důležitost sociální hierarchie v rrímské společnosti.

V rámci přizvání otroků ke stolu tedy v Satirikonu můžeme vidět reflexi konfliktu ř́mského sociálního a právního vnímání otroků. Dále nám demonstruje vývoj forem manumisse a dokládá, že Satirikon je třeba vidět v kontextu doby před vývojem manumissio per mensam, nebot' přizvání otroků ke stolu zde nemá ani náznakem účinky manumisse.

\section{Závěr}

Na příkladu Satirikonu můžeme vidět, že jakkoliv považoval římský právní systém otroka za věc, rrímská společnost se s jeho inherentní lidskostí na společensko-právní úrovni musela neustále vyrovnávat.

Satirikon nám také připomíná, že v př́ípadě Říma v období raného principátu otroctví nebylo otázkou několika málo jednotlivců, nýbrž ekonomicky a početně významné skupiny. Obzvláště dobře toto vidíme na počtu narozených otroků, jakožto nástroje indikace ekonomického blahobytu svého pána, na právní úpravě odpovědnosti za vady při koupi otroka, i ve snaze o „management“ otroků v podání Trimalchiona.

Na důkazy o individuální iniciativě otroků je Satirikon skoupější, než bychom podle moderních teorií čekali. Ani manumissio inter amicos, ani manumissio testamento neposkytují důkazy o postavení otroků v těchto procesech jako cokoliv jiného než jejich objektu. Roli zde nehraje ani koncept meritu jednotlivce, ledaže je popřen.

Satirikon nám však proti očekávání nabízí jinou perspektivu na otroctví jako takové, když nás nutí přemýšlet nad různými variantami motivací pro dobrovolný vstup svobodného jednotlivce do otrockého stavu. Celkově nemohu než hodnotit Hostinu u Trimalchiona jako sice překvapivý, nicméně užitečný nástroj pro poznání římského práva. A naopak, i římské právo může být přínosné pro naše chápání Satirikonu.

\footnotetext{
143 Tamtéž.

144 Tamtéž.
} 